\title{
Nerve regeneration in vascularized composite allotransplantation: current strategies and future directions
}

\author{
Anirudh Arun, Nicholas B. Abt, Sami Tuffaha, Gerald Brandacher, Angelo A. Leto Barone \\ Department of Plastic and Reconstructive Surgery, Johns Hopkins University School of Medicine, Baltimore, MD 21287, USA.
}

Address for correspondence: Dr. Angelo A. Leto Barone, Department of Plastic and Reconstructive Surgery, Johns Hopkins University School of Medicine, Baltimore, MD 21287, USA. E-mail: aletobarone@jhmi.edu

\begin{abstract}
Vascularized composite allotransplantation (VCA) has emerged as a viable treatment option for limb and face reconstruction of severe tissue defects. Functional recovery after VCA requires not only effective immunosuppression, but also consideration of peripheral nerve regeneration to facilitate motor and sensory reinnervation of donor tissue. At the time of transplantation, the donor and recipient nerves are typically coapted in an end-to-end fashion. Following transplantation, there are no therapies available to enhance nerve regeneration and graft reinnervation, and functional outcomes are dependent on the recipients' innate regenerative capacities. Functional outcomes to date have been promising, but there is still much room for improvement, studies have demonstrated reliable return of protective sensation (pain, thermal, gross tactile), while discriminative sensation and motor function show more inconsistent results. In order to maximize the benefit afforded to the by VCA, we must develop consistent and reliable procedures and therapies to ensure effective nerve regeneration and functional outcomes. New technologies, such as nerve guidance conduits and fibrin glues, and the use of stem cells to facilitate nerve regeneration remain untested in VCA but are proving worthwhile in the context of peripheral nerve repair. VCA presents a unique set of challenges with regards to surgical techniques, postoperative regimen, and health of donor tissue. In this review, we discuss current challenges underlying achievement of nerve regeneration in VCA and discuss novel technologies and approaches to translate nerve regeneration into functional restoration.
\end{abstract}

Key words:

Adipose-derived stem cells, allograft, fibrin glue, nerve regeneration, tacrolimus, vascularized composite allotransplantation

\section{INTRODUCTION}

The field of vascularized composite allotransplantation (VCA) has rapidly developed over the past few decades, propelled by major advancements in surgical technique and posttransplant immunosuppression. VCA differs from solid organ transplantation (SOT) in the composition of

\begin{tabular}{|l|l|}
\hline \multicolumn{2}{|c|}{ Access this article online } \\
\hline Quick Response Code: & Website: \\
\hline & www.parjournal.net \\
\cline { 2 - 3 } & \\
\hline & \\
&
\end{tabular}

the transplanted tissue, whereas SOT generally involves one or a few organs and associated cell types, VCA tissues are composed of skin, vascular structures, nerves, muscles, bone, and connective tissue. ${ }^{[1]}$ The enhanced immunogenicity of such composite tissues proved to be a major roadblock in the success of these transplants in the long-term, but the development and use of multiple immunosuppressive drugs, such as tacrolimus (FK506), have significantly reduced incidence of rejection. ${ }^{[2]}$ VCA can currently be performed in various body regions, including, but not limited to, the hand, the proximal upper extremity, and the face. ${ }^{[1]}$

A major challenge of VCA over SOT is that reperfusion of tissues is not sufficient to restore function, instead, functional recovery in VCA is dependent on the recipient's 
axons regenerating into the graft and reinnervating the transplanted muscle and skin, so as to establish motor control and receive sensory input. ${ }^{[1]}$ Nerve damage is inevitable in the process of transplantation, from peripheral axonal degeneration occurring from the time of organ harvest to surgical reconnection of the donor tissue to the host. Host cortical reorganization plays a paramountrole in the restoration of function, as the lack of sensory input from the injured or missing body region results in aberrant cortical response to restoration of sensory input from, and motor output to, the newly innervated tissue following prolonged periods of denervation. ${ }^{[3]}$ Peripheral nerve regeneration is a slow process, occurring at $1-3 \mathrm{~mm} /$ day, partly depending on the microenvironment surrounding axonal sprouts and the caliber of the nerve. ${ }^{[4]}$

Thus, there exists a need for more effective and consistent strategies for nerve regeneration in VCA. This area is a popular field of study in the context of peripheral neuropathy repair, but the VCA context provides unique challenges in the necessity for immunosuppression and the circumstances in which the transplantation is performed.

\section{PATHOPHYSIOLOGY OF NERVE DAMAGE AND REGENERATION}

Following transplantation, axons within the graft undergo Wallerian degeneration. Originally thought to be mediated by impaired transport of nutrients to distal axonal segments and subsequent death, Wallerian degeneration is now considered a product of a self-destruct program distinct from that of apoptosis. ${ }^{[5]}$

Although Wallerian degeneration ultimately claims axons distal to the site of organ harvest, the reorganization of Schwann cells and macrophages around the dying axons fosters an environment that favors axonal regeneration. However, in the context of VCA, this process is affected by the presence of widespread axonal damage and by the need for a balance between immunosuppression and tissue rejection.

Due to the transplantation process, all cellular nerve components distal to the transection point are derived from donor populations. Regeneration of host peripheral nerves requires host-derived Schwann cells to populate the distal stump, which in turn requires proliferative and migration signals. Induction of these signals seems to require partial rejection of the VCA to eliminate donor Schwann cells. Thus, immunosuppression regimens should be carefully determined to provide optimal nerve regeneration through optimal host Schwann cell proliferation and migration while avoiding greater tissue injury during the controlled rejection process. The complete lack of a rejection period may potentially block host Schwann cell migration, leading to impaired peripheral nerve growth. If rejection leads to rapid donor Schwann cell death, unsupported endoneurium may degenerate, blocking further regeneration. ${ }^{[6]}$

\section{CURRENT SURGICAL STRATEGIES FOR NERVE REPAIR AND REGENERATION}

\section{Surgical coaptation (tension-free repair)}

Because additional nerve length can usually be harvested from the donor, tension-free direct end-to-end neurrorraphy of recipient and donor nerve stumps can typically be achieved. Nerve coaptations have been and are still widely used for various procedures in reconstruction, peripheral nerve injury repair, and in VCA. Opening of the donor nerve perineurium and induction of deliberate nerve injury during end-to-side coaptation has been shown to increase the regeneration of axons from the host into donor axons. ${ }^{[7]}$ In the context of facial transplants, tension-free nerve coaptations have been shown to have the most predictable and reliable results in nerve reconstruction. ${ }^{[8]}$ Performing the neurotomy in the epineurial vs. perineurial layer has not yielded a definitive determination of which procedure yields the best postoperative functional results. ${ }^{[9]}$

Nerve transfers are another method by which healthy axons that traditionally serve one area can be rerouted and coapted to provide sensory and motor function to another. However, the clinical applicability of this procedure is untested in VCAs, in the context of the cortical somatosensory reorganization of these redirected sensory and motor domains. ${ }^{[10]}$

\section{Nerve autograft}

Nerve autografting is a surgical procedure that allows for repair of relatively long lesion gaps with the patient's own tissues when nerve coaptation cannot be performed without excess tension on the nerve stumps. Although the graft can provide the scaffold for regrowth with Schwann cells and neurotrophic factors, there is obvious secondary morbidity associated with graft harvest. Nerve autografting has primarily been used in a variety of clinical scenarios requiring nerve repair. ${ }^{[11]}$ Since allografts from donor nerve tissue can be supplemented to the existing composite transplantation without any additional immunosuppressive burden, nerve autografts have limited use in the context of VCA. In addition, challenges in large-caliber nerve revascularization and limited capacity for diffusion-mediated perfusion of such nerves must be taken into consideration. ${ }^{[12]}$

\section{Nerve allograft}

While autografts are considered ideal in the case of peripheral nerve damage since these grafts do not face any immunological mismatch, such is not the case in nerve allografts. However, the primary benefit of this latter method is that the secondary morbidity associated with autograft harvesting, such as sensory loss and scarring, is avoided. ${ }^{[13]}$ When performed in the context of VCA, where immunosuppression is already used to avoid rejection of the primary tissue, use of additional nerve allografts from the cadaveric source of the VCA tissue to ensure tension-free nerve coaptation does not add new immunological consequences. Furthermore, 
immunosuppression following allografts may be discontinued after a period of treatment after nerve regeneration becomes present. ${ }^{[14]}$ Allografts can also be processed in such a way as to reduce their antigenicity by means of decellularization, although nerve growth can suffer from lack of extracellular signaling cues. ${ }^{[12]}$

It has been shown that the cessation of immunosuppression is necessary for replacement of donor Schwann cells in the allograft with those of the host. In a mouse model of sciatic nerve allografts, a continuous postgrafting treatment with cyclosporin A maintained allograft association with donor Schwann cells until a "chronic rejection process" prevailed. This led to clearance of donor Schwann cells and subsequent replacement by host Schwann cells. However, to most efficiently facilitate replacement of donor Schwann cells with those of the host, a temporary immunosuppressive regimen to gradually allow for rejection, is recommended. ${ }^{[15]}$ This controlled rejection process allows for a gradual replacement of Schwann cells such that the growing axons maintain associations with endoneurial Schwann cells. If the replacement does not occur and an acute rejection process suddenly destroys donor Schwann cells supporting host axonal growth, then the entire regenerative process may be compromised.

Outcomes following repair of mid-level brachial plexus injuries with cadaveric/living-related donor nerve allografts in eight patients revealed no complications during or immediately after the operation. Postprocedure immunosuppression included basiliximab, tacrolimus, azathioprine, and co-trimoxazole. Seven of these patients displayed return of motor and sensory function. The eighth was noncompliant with the posttransplant immunosuppressive regimen, leading to impaired motor and sensory regeneration. ${ }^{[16]}$

\section{Tacrolimus (FK506)}

Tacrolimus represents the current backbone of conventional immunosuppressive regimen in SOT. Surprisingly, its use was also shown to have an enhanced effect on nerve regeneration in a dose-dependent, calcineurin-independent mechanism. ${ }^{[17]}$ This combination of effects makes this drug very appealing in the context of VCA. Tacrolimus sustains this effect with both systemic and local administrations. ${ }^{[18]}$

Specific to applications in VCA, administration of tacrolimus in a swine model of ulnar nerve grafting demonstrated doubling of nerve growth parameters (nerve density, mean fiber count) postautograft. In allografts, tacrolimus was necessary for posttransplant neuroregeneration, as the absence of the drug abolished regeneration altogether. ${ }^{[19]}$ Early studies of reinnervation of hemifacial VCAs in rats revealed that immunosuppression provided by tacrolimus coupled with nerve repair in the form of epineurial neurorraphies was successful in developing and maintaining sensory reinnervation of the graft tissues. ${ }^{[20]}$ Tacrolimus used in an orthotopic rat hind limb transplant model was shown to enhance neural regeneration, further enhanced when a bone marrow-derived stem cell (BMSC) suspension was injected into the distal end of the injured nerve. ${ }^{[21]}$ Low dose tacrolimus $(0.1 \mathrm{mg} / \mathrm{kg} / \mathrm{day})$ in peripheral nerve regeneration in rat sciatic nerve transplantation model demonstrated significant re-myelination and regeneration of the transected and transplanted nerve. ${ }^{[22]}$ Tacrolimus was also shown to enhance nerve repair following nerve crush injury in sciatic nerves in rats as compared to cyclosporin $\mathrm{A}$, which had no effect on the rate of axonal regeneration. ${ }^{[23]}$

With respect to Schwann cell migration, tacrolimus administration after sciatic nerve allografts in mice demonstrated rapid host cell migration followed by a slow replacement phase after 15 weeks (replacement of donor Schwann cells by those of the host). Controlled withdrawal of tacrolimus in this period can accelerate the replacement process. ${ }^{[24]}$ Temporally controlling the onset of an acute rejection process either early (5 days posttransplant) or late ( 8 weeks posttransplant) in the regenerative timeframe demonstrated differing degrees of repair. The group undergoing early rejection had a significantly better functional recovery in innervated muscles than those undergoing late rejection. Interestingly, immunohistochemical staining for Schwann cells revealed no difference in staining intensity between late and early rejection groups, although neural fiber width was decreased in late rejection rats, potentially due to impaired myelination production from damaged Schwann cells. ${ }^{[25]}$

The use of tacrolimus in posttransplant immunosuppressive regimens can enhance nerve regeneration and growth of axon sprouts into donor tissue. Further work remains to be done regarding elucidation of the exact mechanism by which tacrolimus affects nerve regeneration, but outcomes data, so far, has been promising. A 3-year follow-up examination of motor recovery after hand transplant in a 47-year-old patient revealed a "remarkable speed" of regeneration. The investigators attribute this to the neurotrophic effects of tacrolimus and note that regeneration is possible even after the patient's median and ulnar nerves had been severed for 14 years prior to the operation and immunosuppressive regimen. ${ }^{[26]}$ However, studies comparing tacrolimus to other immunosuppressive modalities and their resulting effects on nerve regeneration have not been conducted. Promising results from animal models, applications in crushed nerve injury models, Schwann cell studies, and preliminary data from VCA point to tacrolimus being a key neurotrophic candidate along with its well-characterized immunosuppressive capacity.

A summary of recent and pertinent publications can be found in Table 1.

\section{Outcomes studies}

Due to the limited number of hand and face transplants, and the diversity of such patients, large sample size analyses of sensory and motor regeneration are challenging, and few have been performed (requiring the establishment of a patient database for longitudinal and cross-sectional outcomes monitoring). Many outcomes studies look into specific or small sets of patients. For example, patient JM, who underwent a partial face transplant at Brigham and Women's Hospital in Boston 
Table 1: Summary of recent publications pertaining to tacrolimus in nerve regeneration

\begin{tabular}{|c|c|c|c|}
\hline Authors & Year & Title & Summary \\
\hline Liu et al. ${ }^{[27]}$ & 2014 & $\begin{array}{l}\text { Rapamycin promotes Schwann cell } \\
\text { migration and nerve growth factor secretion }\end{array}$ & $\begin{array}{l}\text { With a similar mechanism of action as tacrolimus, rapamycin } \\
\text { was demonstrated to enhance nerve regeneration at lower } \\
\text { concentrations than tacrolimus, although Schwann cell } \\
\text { proliferation was not affected }\end{array}$ \\
\hline Mekaj et al. ${ }^{[28]}$ & 2014 & $\begin{array}{l}\text { Application of topical pharmacological } \\
\text { agents at the site of peripheral nerve } \\
\text { injury and methods used for evaluating the } \\
\text { success of the regenerative process }\end{array}$ & $\begin{array}{l}\text { While topical administration of tacrolimus over the site of } \\
\text { peripheral nerve injury enhances nerve regeneration and } \\
\text { functional recovery, the repair process remains sub-optimal }\end{array}$ \\
\hline Yan et al. ${ }^{[25]}$ & 2013 & $\begin{array}{l}\text { Nerve regeneration in rat limb allografts: } \\
\text { evaluation of acute rejection rescue }\end{array}$ & $\begin{array}{l}\text { In limb transplant, early rejection led to prompt rescue of the } \\
\text { regenerating axons, while late rejection affected motor function } \\
\text { the most }\end{array}$ \\
\hline Song et al..$^{[21]}$ & 2012 & $\begin{array}{l}\text { Use of FK506 and bone marrow } \\
\text { mesenchymal stem cells for rat hind limb } \\
\text { allografts }\end{array}$ & $\begin{array}{l}\text { In hindlimb allograft, treatment with tacrolimus and local BMSC } \\
\text { injection enhanced sciatic nerve regrowth with increased } \\
\text { presence of Schwann cells }\end{array}$ \\
\hline Que et al..$^{[29]}$ & 2012 & $\begin{array}{l}\text { Tacrolimus reduces scar formation and } \\
\text { promotes sciatic nerve regeneration }\end{array}$ & $\begin{array}{l}\text { Treatment of sciatic nerve transection with tacrolimus gavage } \\
\text { in rats demonstrated enhanced regeneration with thicker and } \\
\text { myelinated fibers and reduced collagen fiber content and scar } \\
\text { area in the area of nerve anastomosis }\end{array}$ \\
\hline Azizi et al..$^{[30]}$ & 2012 & $\begin{array}{l}\text { Effects of topically administered FK506 on } \\
\text { sciatic nerve regeneration and reinnervation } \\
\text { after vein graft repair of short nerve gaps }\end{array}$ & $\begin{array}{l}\text { Loading of an inside-out-vein graft with tacrolimus demonstrated } \\
\text { an increase in the number and diameter of myelinated } \\
\text { regenerating fibers in the repair of a rat sciatic nerve injury model }\end{array}$ \\
\hline Yan et al..$^{[31]}$ & 2012 & $\begin{array}{l}\text { Efficacy of short-term FK506 administration } \\
\text { on accelerating nerve regeneration }\end{array}$ & $\begin{array}{l}\text { Short-term administration of tacrolimus in a posttransection injury } \\
\text { model yielded significant benefits in functional motor recovery }\end{array}$ \\
\hline Toll et al..$^{[18]}$ & 2011 & $\begin{array}{l}\text { The role of immunophilin ligands in nerve } \\
\text { regeneration }\end{array}$ & $\begin{array}{l}\text { Systemic tacrolimus administration, as well as other } \\
\text { nonimmunosuppressive immunophilins, enhances nerve } \\
\text { regeneration }\end{array}$ \\
\hline Whitlock et al..[24] & 2010 & $\begin{array}{l}\text { Dynamic quantification of host Schwann cell } \\
\text { migration into peripheral nerve allografts }\end{array}$ & $\begin{array}{l}\text { GFP-tagged host Schwann cells followed after nerve allograft } \\
\text { procedure and tacrolimus administration revealed definitive } \\
\text { migration patterns into the donor tissue }\end{array}$ \\
\hline Li et al..$^{[32]}$ & 2010 & $\begin{array}{l}\text { ImmunophilinFK506 loaded in chitosan } \\
\text { guide promotes peripheral nerve } \\
\text { regeneration }\end{array}$ & $\begin{array}{l}\text { Repair of rat sciatic nerve injury model with a chitosan guide } \\
\text { loaded with tacrolimus demonstrated enhanced electrophysiology } \\
\text { following nerve repair as well as increased maturity of myelinated } \\
\text { axons }\end{array}$ \\
\hline Rustemeyer et al. ${ }^{[33]}$ & 2010 & $\begin{array}{l}\text { Administration of low-dose FK506 } \\
\text { accelerates histomorphometric regeneration } \\
\text { and functional outcomes after allograft } \\
\text { nerve repair in a rat model }\end{array}$ & $\begin{array}{l}\text { Repair of rat sciatic nerve injury model with isograft transplant } \\
\text { and tacrolimus demonstrated enhanced functional recovery in } \\
\text { walking-track analysis at low doses of drug }\end{array}$ \\
\hline Rustemeyer et al. ${ }^{[22]}$ & 2009 & $\begin{array}{l}\text { Histomorphological and functional impacts } \\
\text { of postoperative motor training in rats after } \\
\text { allograft sciatic nerve transplantation under } \\
\text { low-dose FK506 }\end{array}$ & $\begin{array}{l}\text { Tacrolimus was shown to demonstrate significant effects on } \\
\text { regeneration following allograft transplantation, although benefits } \\
\text { of motor training in addition to tacrolimus were not observed }\end{array}$ \\
\hline Landin et al. ${ }^{[20]}$ & 2008 & $\begin{array}{l}\text { Functional outcome after facial allograft } \\
\text { transplantation in rats }\end{array}$ & $\begin{array}{l}\text { In hemifacial transplant, direct nerve repair of facial and } \\
\text { trigeminal nerves yielded the best clinical and neurophysiological } \\
\text { recovery of the graft }\end{array}$ \\
\hline Jensen et al. ${ }^{[19]}$ & 2005 & $\begin{array}{l}\text { Effect of FK506 on peripheral nerve } \\
\text { regeneration through long grafts in inbred } \\
\text { swine }\end{array}$ & $\begin{array}{l}\text { Treatment with systemic tacrolimus demonstrated enhanced } \\
\text { axonal regeneration in nerve autografts and allografts in swine }\end{array}$ \\
\hline Owen et al. ${ }^{[26]}$ & 2001 & $\begin{array}{l}\text { Peripheral nerve regeneration in human } \\
\text { hand transplantation }\end{array}$ & $\begin{array}{l}\text { Inclusion of tacrolimus in the postoperative immunosuppression } \\
\text { of a } 1998 \text { hand transplantation in France was hypothesized to } \\
\text { contribute significantly to peripheral nerve regeneration, as well } \\
\text { as surgical technique/skill and neurotrophic factors secreted by } \\
\text { the patient's own nerves }\end{array}$ \\
\hline Wang et al. ${ }^{[23]}$ & 1997 & $\begin{array}{l}\text { Comparative dose-dependence study of } \\
\text { FK506 and cyclosporin A on the rate of } \\
\text { axonal regeneration in the rat sciatic nerve }\end{array}$ & $\begin{array}{l}\text { Tacrolimus administered at } 5 \mathrm{mg} / \mathrm{kg} \text { to rats in a sciatic nerve } \\
\text { crush injury model demonstrated significant increase in the rate } \\
\text { of nerve regeneration as compared to that with cyclosporin } \mathrm{A} \\
\text { administration }\end{array}$ \\
\hline
\end{tabular}

BMSC: Bone marrow-derived stem cell, FK506: Tacrolimus, GFP: Green fluorescent protein

with coaptation of "all identifiable motor and sensory nerves as distally as recipient anatomy allows" achieved, after three years posttransplant, return of pressure sensation to $92 \%$ of the allograft surface with poorer pressure threshold over the nose. Return of discriminatory sensation and muscle strength was more variable. ${ }^{[34]}$
To aggregate data on functional outcomes following hand transplantation, the International Registry on Hand and Composite Tissue Transplantation was developed. A 2004 publication following 18 male patients who underwent upper extremity transplantations between 1998 and 2004 at various levels reported $100 \%$ patient and graft survival 
and universal return of protective sensation (pain, thermal, and gross tactile sensation) in all grafted hands. Results in discriminative sensation and motor recovery were more variable across these patients. ${ }^{[35]}$ A 2010 publication following 49 hands transplanted between 1998 and 2010 across 33 patients revealed universal recovery of protective sensation and more variable recovery of discriminatory sensation and motor function in grafts at least 1 year posttransplant. ${ }^{[36]}$ While these results look promising, it appears that success can be further optimized in the realm of motor regeneration.

Pomahac et al. $^{[37]}$ reported 1 year postoperative functional outcomes of a partial face transplant of a 59-year-old male following an electrical burn injury. "Meticulous neurorrhaphy" was used to bring together the buccal, infraorbital, and branches of facial nerves. Protective and discriminatory sensations returned to the entire graft by 6 months, and symmetrical smiling was achieved by 1 year.

A 2009 study compared functional recovery in a patient who received a dominant mid-forearm transplantation to that of four patients who underwent mid-forearm replantations following traumatic amputation. The two procedures vary in certain regards, including longer ischemic times in transplantation as compared to replantation, excess allograft tissue requirements for transplants, and the unique need for cortical somatosensory reorganization following a transplant. While the transplant demonstrated increased innervation of intrinsic hand muscles (hypothesized to be due to the effects of tacrolimus), grip strength remained greater in replantations, potentially due to muscle fibrosis and atrophy in the recipient's proximal forearm stump. ${ }^{[38]}$

Post-VCA cortical reorganization has been studied closely, since recovery of motor and sensory function requires not only peripheral nerve regeneration, but the reestablishment of cortical areas representing those regions. Since VCAs are often performed many years after the loss of the limb, underlying cortical plasticity leads to loss of that limb's representation in primary motor (M1) cortex and primary somatosensory (S1) cortex. Relatively acute reestablishment of afferent and efferent pathways in VCA has been shown to result in significant cortical reorganization. ${ }^{[39,40]}$ A functional magnetic resonance imaging (fMRI) study of hand and elbow representations in $\mathrm{M} 1$ in the months following abilateral hand transplantation revealed a reversal of the cortical reorganization induced by that amputation in a patient who underwent traumatic bilateral amputation 4 years in advance. ${ }^{[41]}$ Similar results were demonstrated with transcranial magnetic stimulation in a patient who underwent bilateral hand transplantation 3 years following traumatic amputation. ${ }^{[42]}$ fMRI evaluation of S1 reorganization in a unilateral hand transplant patient 35 years following traumatic amputation demonstrated the significant return of cortical activity despite such a prolonged absence of a limb. ${ }^{[43]}$

A study comparing cortical reorganization in 2 patients, one of whom underwent bilateral hand transplantation 6 years following traumatic amputation, and another who underwent hand replantation $2 \mathrm{~h}$ after traumatic amputation, revealed several observations in the reorganization process. The authors observe that supplementary motor area activation is resistant to reorganizing effects in long-term amputation, and this is more prominently seen in M1. Activation patterns in M1 increased over 2 years following the bilateral transplantation. In the patient undergoing hand replantation, structural differences in cortical representation were not observed, suggesting a functional cortical reorganization instead. ${ }^{[44]}$ Magnetoencephalographic study of cortical representation in 13 patients following limb replantation found a negative correlation between the extent of reorganization and patient-reported pain following replantation. ${ }^{[4]}$

Ultimately, forming comparisons between patients, grafts, and outcomes studies are complicated by varying degrees of existing transplant-area injury in recipients, differences in the circumstances under which donor VCA tissue is procured, and surgical protocols and challenges unique to each procedure. However, aggregation of outcomes is necessary to determine overarching trends since the number of patients undergoing VCA transplantation remains relatively low.

A summary of recent and pertinent publications regarding functional outcomes in VCA can be found in Table 2, and regarding cortical reorganization in VCA in Table 3.

\section{FUTURE DIRECTIONS}

\section{Nerve guidance conduits}

The use of nerve guidance conduits (NGCs) to appose nerve stumps protects against scar infiltration and the development of neuromas, thereby enhancing the fidelity of regeneration. ${ }^{[48]}$ A NGC is a doubly open-ended tube that requires separated nerve ends to be attached to either end of the structure, and the internal composition provides a protected environment for nerve sprouts to extend longitudinally towards the opposing end. ${ }^{[4]}$ Early versions of NGCs only demonstrated the limited extent of repair over a few centimeters. ${ }^{[50]}$

With respect to VCA, however, the benefit of NGCs has not been studied in humans, as the gold standard remains surgical coaptation with or without the use of nerve allografts. This technology has primarily been used in the repair of peripheral nerve damage, and a review of studies published through 2006 evaluating close to three hundred patients reported "satisfactory" results in some patients experiencing suboptimal results. At this point, NGCs are primarily limited to the repair of short lesion gaps, but advances in this technology seek to increase the feasibility and consistent success of its use. ${ }^{[51]}$ Currently, the theoretical benefits of using NGC over nerve allograft in VCA are limited since donor allografts can be utilized to fill large gaps without additional immunosuppression or without concerns for donor-site morbidity in the cadaveric donor.

\section{Chondroitinase}

Chondroitin sulfate proteoglycans (CSPGs) are found in the extracellular matrix and are known to inhibit axonal 
Table 2: Summary of recent publications pertaining to functional outcomes in VCA

\begin{tabular}{|c|c|c|c|}
\hline Authors & Year & Title & Summary \\
\hline Diaz-Siso et al. ${ }^{[34]}$ & 2013 & $\begin{array}{l}\text { Facial allotransplantation: a 3-year } \\
\text { follow-up report }\end{array}$ & $\begin{array}{l}\text { Face transplant of a } 2009 \text { patient demonstrated near-normal } \\
\text { sensation after } 3 \text {-year, along with improving motor function }\end{array}$ \\
\hline Unadkat et al. ${ }^{[46]}$ & 2013 & $\begin{array}{l}\text { Functional outcomes following multiple } \\
\text { acute rejections in experimental VCA }\end{array}$ & $\begin{array}{l}\text { Multiple acute rejection episodes in rat orthotopichindlimb transplants } \\
\text { led to decreased motor function due to muscle atrophy and fibrosis, } \\
\text { although axon density and electrophysiology remained intact }\end{array}$ \\
\hline Pomahac et al. ${ }^{[37]}$ & 2011 & $\begin{array}{l}\text { Restoration of facial form and function } \\
\text { after severe disfigurement from burn } \\
\text { injury by a composite facial allograft }\end{array}$ & $\begin{array}{l}\text { 1-year follow-up of a 59-year-old patient with face transplant } \\
\text { demonstrated recovery of sensation and basic motor function in } \\
\text { emotional display, speech, and feeding }\end{array}$ \\
\hline Petruzzo et al. ${ }^{[36]}$ & 2010 & The IRHCTT. Transplantation & $\begin{array}{l}\text { Analysis of } 49 \text { transplanted hands revealed universal recovery of } \\
\text { protective sensation and return of tactile and discriminative sensation } \\
\text { in most grafts }\end{array}$ \\
\hline Jablecki et al. ${ }^{[38]}$ & 2009 & $\begin{array}{l}\text { A detailed comparison of the functional } \\
\text { outcome after mid-forearm replantations } \\
\text { versus midforearm transplantation }\end{array}$ & $\begin{array}{l}\text { Comparison of forearm transplant to replantation in human patients } \\
\text { revealed greater grip strength in replantation but better recovery of } \\
\text { sensation in transplantation }\end{array}$ \\
\hline Lanzetta et al. ${ }^{[35]}$ & 2005 & The IRHCTT. Transplantation & $\begin{array}{l}\text { Analysis of } 18 \text { hand/forearm/thumb transplants revealed universal } \\
\text { graft survival, achievment of protective sensation, and recovery of } \\
\text { enough motor activity for most daily activities }\end{array}$ \\
\hline
\end{tabular}

VCA: Vascularized composite allotransplantation, IRHCTT: International Registry on Hand and Composite Tissue Transplantation

Table 3: Summary of recent publications pertaining to cortical reorganization in VCA

\begin{tabular}{|c|c|c|c|}
\hline Authors & Year & Title & Summary \\
\hline Blume et al. ${ }^{[45]}$ & 2014 & $\begin{array}{l}\text { Cortical reorganization after } \\
\text { macroreplantation at the upper extremity: } \\
\text { a magnetoencephalographic study }\end{array}$ & $\begin{array}{l}\text { Patient-reported pain was found to be negatively correlated with extent } \\
\text { of cortical reorganization following limb transplantation in a study of } \\
13 \text { patients }\end{array}$ \\
\hline Vargas et al..$^{[42]}$ & 2008 & $\begin{array}{l}\text { Re-emergence of hand-muscle } \\
\text { representations in human motor cortex } \\
\text { after hand allograft }\end{array}$ & $\begin{array}{l}\text { TMS of patient LB, who underwent bilateral hand transplantation 3-year } \\
\text { after traumatic amputation demonstrated M1 representation reestablished } \\
\text { to the newly attached muscles within } 10 \text { months posttransplant }\end{array}$ \\
\hline Frey et al. ${ }^{[43]}$ & 2008 & $\begin{array}{l}\text { Chronically deafferented sensory cortex } \\
\text { recovers a grossly typical organization } \\
\text { after allogenic hand transplantation }\end{array}$ & $\begin{array}{l}\text { Hand transplant of a patient } 35 \text { years postamputation revealed S1 } \\
\text { reorganization within } 4 \text { months, re-establishing gross hand cortical } \\
\text { representation }\end{array}$ \\
\hline Brenneis et al.. ${ }^{[44]}$ & 2005 & $\begin{array}{l}\text { Cortical motor activation patterns } \\
\text { following hand transplantation and } \\
\text { replantation }\end{array}$ & $\begin{array}{l}\text { M1 reorganization was most pronounced in hand transplantation and } \\
\text { compared to replantation, while SMA was resistant to reorganization in } \\
\text { long-term amputation }\end{array}$ \\
\hline Giraux et al.[41] & 2001 & $\begin{array}{l}\text { Cortical reorganization in motor cortex } \\
\text { after graft of both hands }\end{array}$ & $\begin{array}{l}\text { Reversal of } \mathrm{M} 1 \text { reorganization following a traumatic bilateral amputation } \\
\text { was reported in the months after a bilateral hand transplantation }\end{array}$ \\
\hline
\end{tabular}

VCA: Vascularized composite allotransplantation, TMS: Transcranial magnetic stimulation, SMA: Supplementary motor area

regeneration. Treatment with chondroitinase, to cleave glycosaminoglycans from and inactivate CSPGs, has been shown to improve nerve regeneration following nerve injury and repair. ${ }^{[52,53]}$ Chondroitinase treatment is part of the processing used in an off-the-shelf decellularized nerve allograft that has been gaining popularity for nerve repair. ${ }^{[54,55 \mid}$ Our group performed a translational study assessing the use of chondroitinase in VCA and found that a single intraneural injection at the time of transplantation resulted in significantly improved axonal regeneration. ${ }^{[56]}$ As such, this may represent a promising therapeutic option to enhance functional outcomes in clinical VCA.

\section{Fibrin glue}

Traditional nerve coaptation requires the suturing of nerves, which leads to traumatic damage to the stumps. Thus, a more optimal ligation technique is needed to avoid this procedurally-induced impairment. Fibrin glue was demonstrated to quickly and efficiently reattach transected ends of nerves. However, Original studies comparing the effectiveness of fibrin glue and suture-based repair demonstrated differing observations on the preservation of electrophysiology across the transected region. ${ }^{[57,58]}$ Decreased regenerative capacity of the glued stumps may be, in part, due to the enhancement of nerve regeneration following traumatic injury to distal nerve segments, as explained earlier.

Recent histological studies of fibrin glue ligations have demonstrated decreased inflammatory response and fibrosis as compared to sutured reattachments. The use of Quixil, a human fibrin glue sealant, also led to better axonal regeneration and alignment of nerve fibers in a rat model of median nerve transection. Additional of nerve growth factor to the fibrin glue led to enhanced nerve regeneration. ${ }^{[59]}$ Incorporation of microspheres that slowly release glial cell-derived neurotrophic factor into fibrin gels encasing the site of transection was also shown to facilitate regeneration. ${ }^{[60]}$ Although research has demonstrated the benefits of fibrin glue, microsuturing remains the mainstay procedure for nerve segment 
Table 4: Summary of recent publications pertaining to ASCs in peripheral nerve gap repair

\begin{tabular}{|c|c|c|c|}
\hline Authors & Year & Title & Summary \\
\hline Kuo et al..[62] & 2014 & $\begin{array}{l}\text { Proteomic analysis in serum of rat hind- } \\
\text { limb allograft tolerance induced by } \\
\text { immunosuppressive therapy with ASCs }\end{array}$ & $\begin{array}{l}\text { Analysis of serum proteome revealed significant differences } \\
\text { after inclusion of ASC in the immunosuppressive regimen with } \\
\text { increased levels of markers for tolerance }\end{array}$ \\
\hline Cheng et al. ${ }^{[75]}$ & 2014 & $\begin{array}{l}\text { Syngeneic ASCs with short-term } \\
\text { immunosuppression induce VCA tolerance in } \\
\text { rats }\end{array}$ & $\begin{array}{l}\text { Addition of ASCs to post-VCA immunosuppressive regimen } \\
\text { results in enhanced tolerance of the VCA graft with elevated } \\
\text { levels of circulating regulatory T cells }\end{array}$ \\
\hline Wu et al..$^{76]}$ & 2014 & $\begin{array}{l}\text { Donor age negatively affects the } \\
\text { immunoregulatory properties of both adipose and } \\
\text { bone marrow derived mesenchymal stem cells }\end{array}$ & $\begin{array}{l}\text { As the age of the stem cell donor increases, the quality of } \\
\text { collected bone marrow and ASCs decreases }\end{array}$ \\
\hline Hsueh et al. ${ }^{[67]}$ & 2014 & $\begin{array}{l}\text { Functional recoveries of sciatic nerve } \\
\text { regeneration by combining chitosan-coated } \\
\text { conduit and neurosphere cells induced from } \\
\text { ASCs }\end{array}$ & $\begin{array}{l}\text { Seeding of a chitosan-coated conduit with neurosphere cells } \\
\text { differentiated from ASCs leads to "substantial improvements in } \\
\text { nerve regeneration" in a } 10 \mathrm{~mm} \text { sciatic nerve lesion in rats }\end{array}$ \\
\hline Watanabe et al. ${ }^{[68]}$ & 2014 & $\begin{array}{l}\text { Undifferentiated and differentiated ASCs } \\
\text { improve nerve regeneration in a rat model of } \\
\text { facial nerve defect }\end{array}$ & $\begin{array}{l}\text { Seeding of silicone conduits with ASCs (both differentiated } \\
\text { and undifferentiated) or Schwann cells to repair a } 7 \mathrm{~mm} \text { facial } \\
\text { nerve lesion in rats demonstrated similar therapeutic results in } \\
\text { nerve regeneration across cell types }\end{array}$ \\
\hline Hundepool et al. ${ }^{[73]}$ & 2014 & $\begin{array}{l}\text { The effect of stem cells in bridging peripheral } \\
\text { nerve defects: a meta-analysis }\end{array}$ & $\begin{array}{l}\text { Meta analysis of in vivo experimentation of nerve conduits } \\
\text { stem cell seeding for nerve gap repair revealed systematically } \\
\text { that use of stem cells results in the most beneficial effects for } \\
\text { reconstruction }\end{array}$ \\
\hline Qureshi et al. ${ }^{[77]}$ & 2014 & $\begin{array}{l}\text { Human adipose-derived stromal/stem cell } \\
\text { isolation, culture, and osteogenic differentiation }\end{array}$ & $\begin{array}{l}\text { Provides methods for the lipoaspiration of ASCs, culture and } \\
\text { preservation of that cell population, synthesis of scaffolds, and } \\
\text { techniques for loading those scaffolds with isolated cells }\end{array}$ \\
\hline Leto Barone et al. ${ }^{[63]}$ & 2013 & $\begin{array}{l}\text { Immunomodulatory effects of ASCs: fact or } \\
\text { fiction }\end{array}$ & $\begin{array}{l}\text { ASCs demonstrate beneficial tolerogenic qualities in } \\
\text { preliminary studies, but further clinical work must be done to } \\
\text { understand this effect }\end{array}$ \\
\hline Ying et al..$^{[78]}$ & 2013 & $\begin{array}{l}\text { Effects of intracavernous injection of ASCs on } \\
\text { cavernous nerve regeneration in a rat model }\end{array}$ & $\begin{array}{l}\text { In a model of cavernous nerve crush injury, injection of } \\
\text { ASCs to the site of injury demonstrated enhanced nerve } \\
\text { regeneration and restoration of erectile function }\end{array}$ \\
\hline Mohammadi et al. ${ }^{[69]}$ & 2013 & $\begin{array}{l}\text { Effects of undifferentiated cultured omental } \\
\text { ASCs on peripheral nerve regeneration }\end{array}$ & $\begin{array}{l}\text { Repair of a } 10 \mathrm{~mm} \text { sciatic nerve lesion with a silicone conduit } \\
\text { seeded with uASCs demonstrated increased numbers and } \\
\text { sizes of regenerating fibers }\end{array}$ \\
\hline Zaminy et al. ${ }^{[79]}$ & 2013 & $\begin{array}{l}\text { Transplantation of schwann cells differentiated } \\
\text { from adipose stem cells improves functional } \\
\text { recovery in rat spinal cord injury }\end{array}$ & $\begin{array}{l}\text { Collagen scaffolds loaded with Schwann cells differentiated } \\
\text { from ASCs effectively support axon regeneration and } \\
\text { functional recovery in } 3 \mathrm{~mm} \text { spinal cord lesions in rats }\end{array}$ \\
\hline Marconi et al. ${ }^{70]}$ & 2012 & $\begin{array}{l}\text { Human adipose-derived mesenchymal stem cells } \\
\text { systemically injected promote peripheral nerve } \\
\text { regeneration in the mouse model of sciatic crush }\end{array}$ & $\begin{array}{l}\text { Intravenous administration of ASCs after sciatic nerve crush } \\
\text { injury in mice demonstrated 'clear therapeutic potential' by } \\
\text { secreting neuroprotective factors }\end{array}$ \\
\hline Shen et al. ${ }^{[80]}$ & 2012 & $\begin{array}{l}\text { Peripheral nerve repair of transplanted } \\
\text { undifferentiated adipose tissue-derived stem } \\
\text { cells in a biodegradable reinforced nerve conduit }\end{array}$ & $\begin{array}{l}\text { Repair of } 10 \mathrm{~mm} \text { sciatic nerve gap with a genipin-gelatin- } \\
\text { tricalcium phosphate conduit seeded with ASCs demonstrated } \\
\text { similar results in regeneration to autologous nerve grafts }\end{array}$ \\
\hline Orbay et al. ${ }^{[72]}$ & 2012 & $\begin{array}{l}\text { Differentiated and uASCs improve function in } \\
\text { rats with peripheral nerve gaps }\end{array}$ & $\begin{array}{l}\text { In a model of } 10 \mathrm{~mm} \text { sciatic nerve gap, repair with various } \\
\text { modalities, including nerve grafts, conduits, and ASC-seeded } \\
\text { conduits, the seeding of the conduit with stem cells yielded } \\
\text { best outcomes in regeneration and nerve conduction velocity }\end{array}$ \\
\hline Faroni et al. ${ }^{[64]}$ & 2011 & $\begin{array}{l}\text { Schwann-like adult stem cells derived from bone } \\
\text { marrow and adipose tissue express GABA type } \\
\text { B receptors }\end{array}$ & $\begin{array}{l}\text { Schwann cells derived from bone marrow and ASCs express } \\
\text { functional GABA-B receptors, which can modulate cellular } \\
\text { function }\end{array}$ \\
\hline Mohammadi et al. ${ }^{[65]}$ & 2011 & $\begin{array}{l}\text { Comparison of beneficial effects of } \\
\text { undifferentiated cultured bone marrow stromal } \\
\text { cells and omental adipose-derived nucleated } \\
\text { cell fractions on sciatic nerve regeneration }\end{array}$ & $\begin{array}{l}\text { In the repair of a } 10 \mathrm{~mm} \text { sciatic nerve lesion with a vein } \\
\text { graft infused with stem cells, ASCs demonstrated enhanced } \\
\text { regenerative effects as compared to those from bone marrow }\end{array}$ \\
\hline
\end{tabular}

VCA: Vascularized composite allotransplantation, ASC: Adipose-derived stem cells, GABA: Gamma-aminobutyric acid, uASC: Undifferentiated

adipose-derived stem cell

ligation and further development of technologies must be performed. ${ }^{[61]}$ To date, due to the high inflammatory response and fibrosis ensuing during their use, fibrin glues offer limited applicability in VCA, particularly given the enhanced regeneration observed following trauma when nerve segments are re-anastomosed with microsurgical techniques. The future development of bioactive fibrin glues that may artificially provide the neurotrophic factors normally present following nerve trauma, may offer a more efficient and consistent alternative for end-to-end ligation of nerve stumps.

\section{Adipose-derived stem cells}

In addition to demonstrating tolerogenic effects in transplanted tissues, ${ }^{|62,63|}$ both BMSCs and adipose-derived stem cells (ASCs) have also been shown to exert positive effects on peripheral nerve regeneration. ${ }^{.64]}$ The relative ease of isolating ASCs and developing Schwann cell populations from this cell type makes them more 
efficient to use than BMSCs. These characteristics, coupled with the observation that there is no significant difference between ASCs and BMSCs in facilitating nerve regeneration, points to ASCs as being a more efficient option in stem cell-based enhancement of nerve regeneration. ${ }^{[65]}$

While the transplantation of Schwann cells into nerve conduits has demonstrated increased regenerative potential, ${ }^{[66]}$ ASCs have also been demonstrated to have a pro-regenerative effect on growing axons. ${ }^{[67-70]}$ The mechanism for this effect is in the differentiation of ASCs into Schwann cell-like phenotypes in the context of nerve injury and regeneration. Interestingly, undifferentiated ASCs (uASCs) can also promote nerve growth. ${ }^{\text {[1] }}$ In vitro differentiation of uASCs into Schwann cells prior to seeding demonstrated no significant difference as compared to uASCs in the graft-guided regeneration of a ten millimeter injury of rat sciatic nerve. ${ }^{\text {[72] }}$ Similar findings were demonstrated in facial nerve repair with uASC/differentiated ASC seeding of the graft. ${ }^{[68]}$ A large meta-analysis published in July 2014 examining data from forty-four animal studies revealed that the use of ASCs in nerve grafts offers significant benefits toward nerve regeneration in sciatic, median, ulnar, and radial nerve lesion models in rats, dogs, monkeys, and mice. ${ }^{\text {[3] }}$

The regenerative benefits of ASCs require their seeding along the path of the growing axon sprouts, as well as being in an environment that maintains the population for the weeks to months required for axonal regrowth. Existing Food and Drug Administration-approved nerve conduits with specialized matrices for ASC maintenance adequately meets these requirements, thereby creating a microenvironment in which such stem cells can readily affect pro-regenerative signals on growing axons in a spatially constrained path. ASCs are capable of secreting nerve growth factors, vascular endothelial growth factor, and brain-derived neurotrophic factor, among a wider set of cytokines and other cell signaling molecules. ${ }^{[1]}$ The strength of a cellular graft over one that merely elutes neurotrophic factors is that the molecular microenvironment can be regulated by ASCs in response to the penetrating sprouts. ${ }^{[74]}$

ASCs prove to be a promising area of research for the facilitation of nerve regeneration in VCA. Early in vivo research demonstrating seeding of these cells into artificial conduits and grafts has provided promising results. However, these remain restricted to animal models of the peripheral nerve lesion. The combined promise of beneficial immunomodulatory effects and enhanced nerve regeneration makes these cells a tantalizing therapeutic supplementation in VCA. The extent of these benefits as a clinical application in VCA remains to be studied.

A summary of recent and pertinent publications regarding ASCs in VCA/nerve regeneration can be found in Table 4.

\section{CONCLUSION}

Sensory and motor regeneration are major hurdles that must be addressed to realize the fullest potential of VCA. Advances continue to be made in peripheral nerve repair, and these results must be explored in the context of transplant surgery. Results in post-VCA functional outcomes continue to improve, and soon, we can expect more consistent, reliable, and faster recovery of sensation and motor control to donor tissues. Exciting advancements in the area of ASC-enhanced nerve regeneration may offer a promising frontier towards addressing this challenging question.

\section{REFERENCES}

I. Chim H, Amer H, Mardini S, Moran SL. Vascularized composite allotransplant in the realm of regenerative plastic surgery. Mayo Clin Proc 20 14;89: I009-20.

2. Fischer S, Lian CG, Kueckelhaus M, Strom TB, Edelman ER, Clark RA, Murphy GF, Chandraker AK, Riella LV, Tullius SG, Pomahac B. Acute rejection in vascularized composite allotransplantation. Curr Opin Organ Transplant 2014;19:531-44.

3. Oliveira JT, Bittencourt-Navarrete RE, de Almeida FM, Tonda-Turo C, Martinez AM, Franca JG. Enhancement of median nerve regeneration by mesenchymal stem cells engraftment in an absorbable conduit: improvement of peripheral nerve morphology with enlargement of somatosensory cortical representation. Front Neuroanat 2014;8: I II.

4. Scheib J, Höke A. Advances in peripheral nerve regeneration. Nat Rev Neurol 2013;9:668-76.

5. Raff MC, Whitmore AV, Finn JT. Axonal self-destruction and neurodegeneration. Science 2002;296:868-7I.

6. Glaus SW, Johnson PJ, Mackinnon SE. Clinical strategies to enhance nerve regeneration in composite tissue allotransplantation. Hand Clin 201 I;27:495-509, ix.

7. Oyamatsu H, Koga D, Igarashi M, Shibata M, Ushiki T. Morphological assessment of early axonal regeneration in end-to-side nerve coaptation models. J Plast Surg Hand Surg 2012;46:299-307.

8. Pomahac B, Pribaz J. Facial composite tissue allograft. J Craniofac Surg 20I2;23:265-7.

9. Lykissas MG. Current concepts in end-to-side neurorrhaphy. World J Orthop 201 I;2:102-6.

10. Audolfsson T, Rodríguez-Lorenzo A, Wong C, Cheng A, Kildal M, Nowinski D, Rozen S. Nerve transfers for facial transplantation: a cadaveric study for motor and sensory restoration. Plast Reconstr Surg 2013; |31:1231-40.

II. Rinker B, Vyas KS. Clinical applications of autografts, conduits, and allografts in repair of nerve defects in the hand: current guidelines. Clin Plast Surg 20I4;4I:533-50.

12. Rivlin M, Sheikh E, Isaac R, Beredjiklian PK. The role of nerve allografts and conduits for nerve injuries. Hand Clin 2010;26:435-46, viii.

13. Moore AM, Kasukurthi R, Magill CK, Farhadi HF, Borschel GH, Mackinnon SE. Limitations of conduits in peripheral nerve repairs. Hand (N Y) 2009;4: 180-6.

14. Mackinnon SE, Doolabh VB, Novak CB, Trulock EP. Clinical outcome following nerve allograft transplantation. Plast Reconstr Surg 200 I; 107: 14 I 9-29.

15. Midha R, Mackinnon SE, Becker LE. The fate of Schwann cells in peripheral nerve allografts. J Neuropathol Exp Neurol 1994;53:316-22.

16. Elkwood Al, Holland NR, Arbes SM, Rose MI, Kaufman MR, Ashinoff RL, Parikh MA, Patel TR. Nerve allograft transplantation for functional restoration of the upper extremity: case series. J Spinal Cord Med 20I I;34:24I-7.

17. Gold BG. FK506 and the role of immunophilins in nerve regeneration. Mol Neurobiol 1997; 15:285-306.

18. Toll EC, Seifalian AM, Birchall MA. The role of immunophilin ligands in nerve regeneration. Regen Med 20II;6:635-52.

19. Jensen JN, Brenner MJ, Tung TH, Hunter DA, Mackinnon SE. Effect of FK506 on peripheral nerve regeneration through long grafts in inbred swine. Ann Plast Surg 2005;54:420-7.

20. Landin L, Cavadas PC, Gonzalez E, Rodriguez JC, Caballero A. Functional outcome after facial allograft transplantation in rats. J Plast Reconstr Aesthet Surg 2008;61:1034-43.

21. Song Y, Wang Z, Wang Z, Zhang H, Li X, Chen B. Use of FK506 and bone marrow mesenchymal stem cells for rat hind limb allografts. Neural Regen Res 20|2;7:268I-8. 
22. Rustemeyer J, Krajacic A, Dicke U. Histomorphological and functional impacts of postoperative motor training in rats after allograft sciatic nerve transplantation under low-dose FK 506. Muscle Nerve 2009;39:480-8.

23. Wang MS, Zeleny-Pooley M, Gold BG. Comparative dose-dependence study of FK506 and cyclosporin A on the rate of axonal regeneration in the rat sciatic nerve. J Pharmacol Exp Ther 1997;282:1084-93.

24. Whitlock EL, Myckatyn TM, Tong AY, Yee A, Yan Y, Magill CK, Johnson PJ, Mackinnon SE. Dynamic quantification of host Schwann cell migration into peripheral nerve allografts. Exp Neurol 2010;225:310-9.

25. Yan Y, MacEwan MR, Hunter DA, Farber S, Newton P, Tung TH, Mackinnon SE, Johnson PJ. Nerve regeneration in rat limb allografts: evaluation of acute rejection rescue. Plast Reconstr Surg 20 I3; I 3 I:e499-5 I I.

26. Owen ER, Dubernard JM, Lanzetta M, Kapila H, Martin X, Dawahra M, Hakim NS. Peripheral nerve regeneration in human hand transplantation. Transplant Proc 200I;33:1720-I.

27. Liu F, Zhang H, Zhang K, Wang X, Li S, Yin Y. Rapamycin promotes Schwann cell migration and nerve growth factor secretion. Neural Regen Res 20।4;9:602-9.

28. Mekaj AY, Morina AA, Bytyqi Cl, Mekaj YH, Duci SB. Application of topical pharmacological agents at the site of peripheral nerve injury and methods used for evaluating the success of the regenerative process. J Orthop Surg Res 2014;9:94

29. Que J, Cao Q, Sui T, Du S, Zhang A, Kong D, Cao X. Tacrolimus reduces scar formation and promotes sciatic nerve regeneration. Neural Regen Res 20I 2;7:2500-6.

30. Azizi S, Mohammadi R, Amini K, Fallah R. Effects of topically administered FK506 on sciatic nerve regeneration and reinnervation after vein graft repair of short nerve gaps. Neurosurg Focus 2012;32:E5.

31. Yan Y, Sun HH, Hunter DA, Mackinnon SE, Johnson PJ. Efficacy of short-term FK506 administration on accelerating nerve regeneration. Neurorehabil Neural Repair 2012;26:570-80.

32. Li X, Wang W, Wei G, Wang G, Zhang W, Ma X. Immunophilin FK506 loaded in chitosan guide promotes peripheral nerve regeneration. Biotechnol Lett 20I0;32:1333-7.

33. Rustemeyer J, van de Wal R, Keipert C, Dicke U. Administration of low-dose FK 506 accelerates histomorphometric regeneration and functional outcomes after allograft nerve repair in a rat model. J Craniomaxillofac Surg 2010;38:134-40.

34. Diaz-Siso JR, Parker M, Bueno EM, Sisk GC, Pribaz JJ, Eriksson E, Annino D, Tullius SG, Pomahac B. Facial allotransplantation: a 3-year follow-up report. J Plast Reconstr Aesthet Surg 2013;66:1458-63.

35. Lanzetta M, Petruzzo P, Margreiter R, Dubernard JM, Schuind F, Breidenbach W, Lucchina S, Schneeberger S, van Holder C, Granger D, Pei G, Zhao J, Zhang X. The international registry on hand and composite tissue transplantation. Transplantation 2005;79:1210-4.

36. Petruzzo P, Lanzetta M, Dubernard JM, Landin L, Cavadas P, Margreiter R, Schneeberger S, Breidenbach W, Kaufman C, Jablecki J, Schuind F, Dumontier $\mathrm{C}$. The international registry on hand and composite tissue transplantation. Transplantation 2010;90:1590-4.

37. Pomahac B, Pribaz J, Eriksson E, Annino D, Caterson S, Sampson C, Chun Y, Orgill D, Nowinski D, Tullius SG. Restoration of facial form and function after severe disfigurement from burn injury by a composite facial allograft. Am J Transplant 201 I; I 1:386-93.

38. Jablecki J, Kaczmarzyk L, Patrzalek D, Domanasiewicz A, Chelmonski A. A detailed comparison of the functional outcome after midforearm replantations versus midforearm transplantation. Transplant Proc 2009;41:5I3-6.

39. Dubernard JM, Sirigu A, Seulin C, Morelon E, Petruzzo P. Fifteen years later: main lessons from composite tissue allografts. Clin Transp/ 2013;1 13-9.

40. Siemionow M, Mendiola A. Methods of assessment of cortical plasticity in patients following amputation, replantation, and composite tissue allograft transplantation. Ann Plast Surg 2010;65:344-8.

41. Giraux P, Sirigu A, Schneider F, Dubernard JM. Cortical reorganization in motor cortex after graft of both hands. Nat Neurosci 2001;4:691-2.

42. Vargas CD, Aballéa A, Rodrigues EC, Reilly KT, Mercier C, Petruzzo P, Petruzzo P, Dubernard JM, Sirigu A. Re-emergence of hand-muscle representations in human motor cortex after hand allograft. Proc Natl Acad Sci U S A 2009;106:7197-202.

43. Frey SH, Bogdanov S, Smith JC, Watrous S, Breidenbach WC. Chronically deafferented sensory cortex recovers a grossly typical organization after allogenic hand transplantation. Curr Biol 2008; 18:1530-4.

44. Brenneis C, Löscher WN, Egger KE, Benke T, Schocke M, Gabl MF, Wechselberger G, Felber S, Pechlaner S, Margreiter R, Piza-Katzer H, Poewe W. Cortical motor activation patterns following hand transplantation and replantation. J Hand Surg Br 2005;30:530-3.
45. Blume KR, Dietrich C, Huonker R, Götz T, Sens E, Friedel R, Hofmann GO, Miltner WH, Weiss T. Cortical reorganization after macroreplantation at the upper extremity: a magnetoencephalographic study. Brain 20|4; I37:757-69.

46. Unadkat JV, Bourbeau D, Afrooz PN, Solari MG, Washington KM, Pulikkottil BJ, Weber DJ, Lee WP. Functional outcomes following multiple acute rejections in experimental vascularized composite allotransplantation. Plast Reconstr Surg 2013;131:e720-30.

47. Breidenbach WC, Gonzales NR, Kaufman CL, Klapheke M, Tobin GR, Gorantla VS. Outcomes of the first 2 American hand transplants at 8 and 6 years posttransplant. J Hand Surg Am 2008;33:1039-47.

48. Félix SP, Pereira Lopes FR, Marques SA, Martinez AM. Comparison between suture and fibrin glue on repair by direct coaptation or tubulization of injured mouse sciatic nerve. Microsurgery 2013;33:468-77.

49. Isaacs J, Browne T. Overcoming short gaps in peripheral nerve repair: conduits and human acellular nerve allograft. Hand (N Y) 20I4;9:13 I-7.

50. Jiang X, Lim SH, Mao HQ, Chew SY. Current applications and future perspectives of artificial nerve conduits. Exp Neurol 20I0;223:86-I0I.

5I. Schlosshauer B, Dreesmann L, Schaller HE, Sinis N. Synthetic nerve guide implants in humans: a comprehensive survey. Neurosurgery 2006;59:740-7.

52. Muir D, Engvall E, Varon S, Manthorpe M. Schwannoma cell-derived inhibitor of the neurite-promoting activity of laminin. J Cell Biol 1989;109:2353-62.

53. Neubauer D, Graham JB, Muir D. Chondroitinase treatment increases the effective length of acellular nerve grafts. Exp Neurol 2007;207: 163-70.

54. Whitlock EL, Tuffaha SH, Luciano JP, Yan Y, Hunter DA, Magill CK, Moore AM, Tong AY, Mackinnon SE, Borschel GH. Processed allografts and type I collagen conduits for repair of peripheral nerve gaps. Muscle Nerve 2009;39:787-99.

55. Brooks DN, Weber RV, Chao JD, Rinker BD, Zoldos J, Robichaux MR, Ruggeri SB, Anderson KA, Bonatz EE, Wisotsky SM, Cho MS, Wilson C, Cooper EO, Ingari JV, Safa B, Parrett BM, Buncke GM. Processed nerve allografts for peripheral nerve reconstruction: a multicenter study of utilization and outcomes in sensory, mixed, and motor nerve reconstructions. Microsurgery 2012;32:I-I4

56. Tuffaha S, Quigley M, Ng T, Gorantla VS, Shores JT, Pulikkottil B, Shestak C, Brandacher G, Lee WP. The effect of chondroitinase on nerve regeneration following composite tissue allotransplantation.J Hand Surg Am 201 I;36: |447-52.

57. Smahel J, Meyer VE, Bachem U. Glueing of peripheral nerves with fibrin: experimental studies. J Reconstr Microsurg 1987;3:21 I-20.

58. Moy OJ, Peimer CA, Koniuch MP, Howard C, Zielezny M, Katikaneni PR. Fibrin seal adhesive versus nonabsorbable microsuture in peripheral nerve repair. J Hand Surg Am 1988; 13:273-8.

59. Ma S, Peng C, Wu S, Wu D, Gao C. Sciatic nerve regeneration using a nerve growth factor-containing fibrin glue membrane. Neural Regen Res 2013;8:3416-22.

60. Wood MD, Gordon T, Kim H, Szynkaruk M, Phua P, Lafontaine C, Kemp SW, Shoichet MS, Borschel GH. Fibrin gels containing GDNF microspheres increase axonal regeneration after delayed peripheral nerve repair. Regen Med 2013;8:27-37.

6I. Owusu A, Mayeda B, Isaacs J. Surgeon perspectives on alternative nerve repair techniques. Hand (N Y) 20I4;9:29-35.

62. Kuo YR, Chen CC, Goto S, Huang YT, Tsai CC, Yang MY. Proteomic analysis in serum of rat hind-limb allograft tolerance induced by immunosuppressive therapy with adipose-derived stem cells. Plast Reconstr Surg 20 |4; 134:12 I3-23.

63. Leto Barone AA, Khalifian S, Lee WP, Brandacher G. Immunomodulatory effects of adipose-derived stem cells: fact or fiction? Biomed Res Int 20I3;20I3:383685.

64. Faroni A, Mantovani C, Shawcross SG, Motta M, Terenghi G, Magnaghi V. Schwann-like adult stem cells derived from bone marrow and adipose tissue express gamma-aminobutyric acid type B receptors. J Neurosci Res 201।;89:1351-62.

65. Mohammadi R, Azizi S, Delirezh N, Hobbenaghi R, Amini K. Comparison of beneficial effects of undifferentiated cultured bone marrow stromal cells and omental adipose-derived nucleated cell fractions on sciatic nerve regeneration. Muscle Nerve 201 I;43:157-63.

66. Rodríguez FJ, Verdú E, Ceballos D, Navarro X. Nerve guides seeded with autologous schwann cells improve nerve regeneration. Exp Neurol 2000; |61:57|-84.

67. Hsueh YY, Chang YJ, Huang TC, Fan SC, Wang DH, Chen J, Wu CC, Lin SC. Functional recoveries of sciatic nerve regeneration by combining chitosan-coated conduit and neurosphere cells induced from adipose-derived stem cells. Biomaterials 20I4;35:2234-44.

68. Watanabe $\mathrm{Y}$, Sasaki R, Matsumine H, Yamato M, Okano T. Undifferentiated and differentiated adipose-derived stem cells improve nerve regeneration in a 
rat model of facial nerve defect. J Tissue Eng Regen Med 2014;DOI: 10.1002/ term.1919.

69. Mohammadi R, Azizi S, Amini K. Effects of undifferentiated cultured omental adipose-derived stem cells on peripheral nerve regeneration. J Surg Res 2013;180:e91-7.

70. Marconi S, Castiglione G, Turano E, Bissolotti G, Angiari S, Farinazzo A, Constantin G, Bedogni G, Bedogni A, Bonetti B. Human adipose-derived mesenchymal stem cells systemically injected promote peripheral nerve regeneration in the mouse model of sciatic crush. Tissue Eng Part A 2012; 18:1264-72

7I. Faroni A, Terenghi G, Reid AJ. Adipose-derived stem cells and nerve regeneration: promises and pitfalls. Int Rev Neurobiol 2013;108:121-36.

72. Orbay H, Uysal AC, Hyakusoku H, Mizuno H. Differentiated and undifferentiated adipose-derived stem cells improve function in rats with peripheral nerve gaps. J Plast Reconstr Aesthet Surg 2012;65:657-64.

73. Hundepool CA, Nijhuis TH, Mohseny B, Selles RW, Hovius SE. The effect of stem cells in bridging peripheral nerve defects: a meta-analysis. J Neurosurg 2014;121:195-209.

74. Widgerow AD, Salibian AA, Kohan E, Sartiniferreira T, Afzel H, Tham T, Evans GR. "Strategic sequences" in adipose-derived stem cell nerve regeneration. Microsurgery 20I4;34:324-30.

75. Cheng HY, Ghetu N, Huang WC, Wang YL, Wallace CG, Wen CJ, Chen HC, Shih LY, Lin CF, Hwang SM, Liao SK, Wei FC. Syngeneic adipose-derived stem cells with short-term immunosuppression induce vascularized composite allotransplantation tolerance in rats. Cytotherapy 20I4;16:369-80.

76. Wu LW, Wang YL, Christensen JM, Khalifian S, Schneeberger S, Raimondi G,
Cooney DS, Lee WP, Brandacher G. Donor age negatively affects the immunoregulatory properties of both adipose and bone marrow derived mesenchymal stem cells. Transpl Immunol 20|4;30:I22-7.

77. Qureshi AT, Chen C, Shah F, Thomas-Porch C, Gimble JM, Hayes DJ. Human adipose-derived stromal/stem cell isolation, culture, and osteogenic differentiation. Methods Enzymol 2014;538:67-88.

78. Ying C, Yang M, Zheng X, Hu W, Wang X. Effects of intracavernous injection of adipose-derived stem cells on cavernous nerve regeneration in a rat model. Cell Mol Neurobiol 20I3;33:233-40.

79. Zaminy A, Shokrgozar MA, Sadeghi Y, Norouzian M, Heidari MH, Piryaei A. Transplantation of schwann cells differentiated from adipose stem cells improves functional recovery in rat spinal cord injury. Arch Iran Med 2013;16:533-4I.

80. Shen CC, Yang YC, Liu BS. Peripheral nerve repair of transplanted undifferentiated adipose tissue-derived stem cells in a biodegradable reinforced nerve conduit. J Biomed Mater Res A 2012;100:48-63.

How to cite this article: Arun A, Abt NB, Tuffaha S, Brandacher G, Leto Barone AA. Nerve regeneration in vascularized composite allotransplantation: current strategies and future directions. Plast Aesthet Res 2015;2:226-35.

Source of Support: Nil, Conflict of Interest: None declared.

Received: 19-02-2015; Accepted: 13-04-2015 